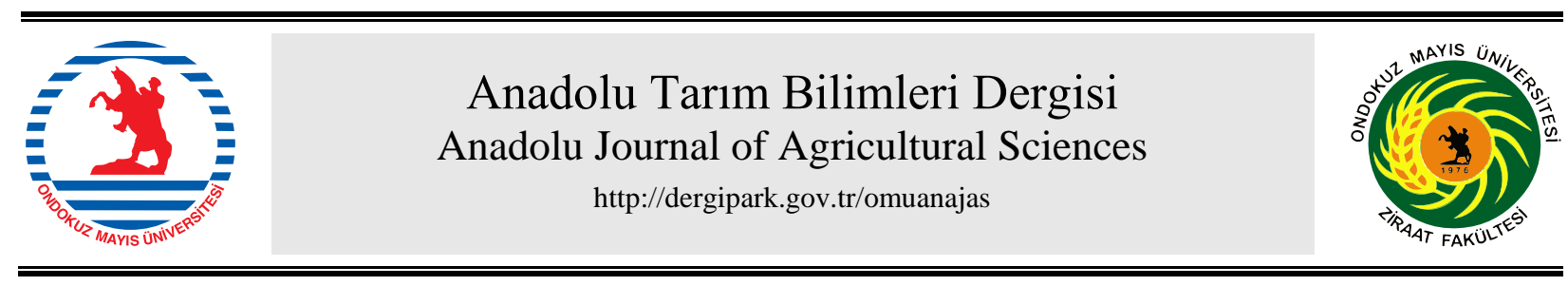

Araştırma/Research

\title{
Burdur Gölü’ndeki seviye değişimi sonucunda ortaya çıkan lakustrin materyalin zamansal ve mekansal değişimi
}

\author{
Gafur Gözükara ${ }^{a^{*}}$, Sevda Altunbaşs ${ }^{\mathrm{b}}$, Mustafa Sarı ${ }^{\mathrm{b}}$ \\ ${ }^{a}$ Eskişehir Osmangazi Üniversitesi, Ziraat Fakültesi, Toprak Bilimi ve Bitki Besleme Bölümü, Eskişehir \\ bAkdeniz Üniversitesi, Ziraat Fakültesi, Toprak Bilimi ve Bitki Besleme Bölümü, Antalya \\ *Sorumlu yazar / Corresponding author:ggozukara@ogu.edu.tr
}

Geliș/Received 19/04/2019 Kabul/Accepted 17/09/2019

ÖZET

Türkiye'nin Göller Bölgesinde yer alan ve Ramsar sulak alanı olan Burdur Gölü, son yıllarda dramatik bir şekilde hızla kurumaktadır. Bu çalışmanın amacı; son 42 yılda (19752017) Burdur Göl seviyesinin azalması ile bazı iklimsel parametreler arasındaki ilişkiyi değerlendirmek ve karasal ortama çıkan lakustrin materyallerin zamana bağlı konumsal ve alansal dağılımlarını tespit etmektir. Burdur Gölü seviyesinin azalması üzerinde etkisi olan iklim ve diğer faktörler sonucunda; göl seviyesinin $13.74 \mathrm{~m}$ alçaldığı $(-\%$ 2) ve göl alanının $211 \mathrm{~km}^{2}$, den $130 \mathrm{~km}^{2}$,ye kadar (-\% 38.39) gerilediği tespit edilmiştir. Ortaya çıkan lakustrin materyalin konumsal dağılımları ise; daha düşük ortalama eğime (\% 0.12) sahip Kuzey Doğu Sahili'nde (KDS) yoğunluk göstermektedir. Burdur Gölü'nün su seviyesinin azalması ile iklimsel parametreler arasındaki ilişki incelendiğinde; göl seviyesindeki azalma ile en güçlü ilişkinin sıcaklık $\left(-0.637^{* *}\right)$ ve toplam buharlaşma $\left(-0.603^{* *}\right)$ arasında olduğu tespit edilmiştir. Yııllı toplam yağış miktarı ile göl seviyesinin azalması arasında, herhangi bir ilişki tespit edilememiş̧ir. Bu sonuçlara göre, Burdur Gölü’nün kurumasında etkili olduğu düşünülen iklim faktörlerine müdahale ederek göl havzasının su bilançosu üzerindeki baskının azaltılması pek mümkün görünmemektedir. $\mathrm{Bu}$ sebeple Burdur Gölü’nün devamlılığını sağlamak için, hatalı arazi kullanımı ve hatalı tarımsal üretim deseni üzerinde gerekli yasal düzenlemelerin acilen yapılması gerekmektedir.

The temporal and spatial changes of the lacustrine material resulting from the level change in the Burdur Lake

\section{ABSTRACT}

Turkey's lake situated in the region and the Ramsar wetlands of Lake Burdur, quickly dry up dramatically in recent years. The aim of this study is; To evaluate the relationship between the reduction of Burdur Lake level and some climatic parameters in the last 42 years (1975-2017) and to determine the spatial and spatial distributions of the lacustrine materials coming into the terrestrial environment. As a result of climate and other factors that have an effect on the decrease of Burdur Lake level; It was determined that the lake level decreased $13.74 \mathrm{~m}(-2 \%)$ and the lake area decreased from $211 \mathrm{~km}^{2}$ to $130 \mathrm{~km}^{2}(-38.39 \%)$. The positional distribution of the resulting lacustrin material is; The North Eastern Coast has a lower average gradient $(0.12 \%)$. When the relationship between the water level of the Burdur Lake and the climatic parameters is examined; It was found that the strongest relationship with the decrease in the lake level was between temperature $(-0.637 * *)$ and total evaporation $(-0.603 * *)$. No relation was found between the total annual rainfall and the decrease in lake level. According to these results, it is unlikely to reduce the pressure on the water balance of the lake basin by interfering with the climate factors which are thought to be
Anahtar Sözcükler:

Burdur Gölü

Göl seviyesi

Lakustrin ana

materyal
Keywords: Lake Burdur Lake level Lacustrine parent material 
effective in the drying of Burdur Lake. For this reason, in order to ensure the continuity of Burdur Lake, it is necessary to make the necessary arrangements on unsuitable land use and agricultural production pattern.

\section{Giriş}

Göller genellikle bulundukları yörenin en çukur topografyasında yer alırlar. Gölün çevresindeki yüksek arazilerden, yüzey akışlarıyla taşınan taşl1-topraklı materyaller, göllerin tabanlarında ve yakın çevrelerinde ylllık ve/veya dönemsel katmanlar şeklinde birikirler (Gözükara ve Altunbaş, 2016). Göl tabanlarında, su ve dalga hareketleri ile zaman içerisinde organize olarak düz ve düze yakın bir topografik yapıya sahip olan bu materyaller "Lakustrin" olarak isimlendirilirler (Tröels, 1955; Merkt ve ark., 1971; Schnurrenberger ve ark., 2003; Sarı, 2015; Gözükara ve Altunbaş, 2016; Soil Survey Manuel, 2017). Tarımsal sulama, içme/kullanma suyu temini, insanların arazi kullanım şekilleri (tarım, balıkçılık ve hayvancılık), kirlilik, şehirleşme, iklim değişikliği ve gölü besleyen kaynakların azalması gibi faktörler sulak alanların dinamik su seviyelerinde ciddi kayiplara neden olurlar (Hartig ve ark., 1997; Stephanie ve ark., 2000; Brinson ve Zedler, 2003; Bassi ve ark., 2014; Fickas ve ark., 2016; Song ve Liu, 2016). Su altında gerçekleşen depolanma olaylarında, taşınıp biriken malzemenin özelliğine bağlı olarak, lakustrin materyallerin bir kısmı veya tamamı, gölün dinamik su seviyesinin azalmasıyla birlikte karasal ortama çıkarlar. Karasal ortama çıkan bu materyaller, Toprak Genetiği Biliminde, "Lakustrin Ana Materyal" olarak isimlendirilirler (Sarı, 2015; Soil Survey Manuel, 2017). Toprak oluşum sürecinde, ana materyal görevi gören lakustrinler, iklim, topoğrafya, biyosfer ve zamanın etkisi ile toprak oluşturmaya (pedolojik prosesler) başlarlar. Farklı fiziko-kimyasal ve mineralojik özelliklere sahip lakustrin ana materyaller üzerinde oluşan topraklarda meydana gelen zamansal ve mekansal farklılıklar ise, onların kullanım şekillerini ve üretkenlik potansiyellerini etkiler (Baktır ve Sarı, 2002; Sarı ve ark., 2003; Altunbaş ve Sarı, 2010; Altunbaş ve Sar1, 2011; Gözükara, 2019).

Türkiye'nin büyük bir bölümü, jeolojik zaman süreçlerinde pek çok defalar su altında kalarak, "eski göl ve deniz tabanı" fizyografyalarına (arazi formlarına) sahip olmuştur. Göllerin ve diğer sulak alanların zamanla ve çeșitli nedenlerle su seviyelerindeki değişimi ve ortaya çıkan alanların tespiti konusunda birçok araştırmacı çalışmalar yapmıştır (Kent ve ark., 2005; Hui ve ark., 2008; Günal ve Özdemir, 2010; Akar ve ark., 2012; Bahadır, 2013; Çatal ve Dengiz, 2015; Çelebi, 2016; Cui ve ark., 2016; Yan ve ark., 2017; Liu ve Yue, 2017). Ortaya çıkan bu alanlar, tarım, sanayi, kentleşme, turizm, yol ve havaalanı gibi amaçlarla kullanılmaktadır. Türkiye'nin Güneybatı'sında “Göller Yöresi” olarak bilinen alanda pek çok sulak alan bulunmaktadır. $\mathrm{Bu}$ sulak alanların en önemlilerinden birisi de Burdur Gölüdür. Burdur Gölü, geçmiş jeolojik zaman süreçlerinde çeşitli kereler çekilmek suretiyle, karasal ortama kavuşmuş ve kavuşmaya devam eden arazilere sahiptir (Roberts, 2003a; Ataol, 2010; Tudryn ve ark., 2013). Burdur Göl Havzası'nda farklı zaman dilimlerinde ve farklı konumlarda, sudan kurtulan bu materyaller üzerinde, çeşitli düzeylerde pedolojik değişim ve dönüşümler yaşanmaya başlamıştır. Bugün; bir kısmı tarımsal üretimde kullanılmakta olan ve halen hiçbir kullanım kararı ve uygulaması bulunmayan lakustrin materyal üzerinde gelişen toprakların, oluşum ve gelişim düzeyleri bilinmemektedir. Buna karşıllk yöre insanları, göl sularının çekilmesi ile karasal ortama çıkmış ve hemen tamamı düz ve/veya düze yakın topografyaya sahip olan bu arazileri tarım, sanayi ve yerleşim alanı olarak kullanmak istemekte ve bu yönde yoğun bir kamuoyu baskısı oluşturmaktadırlar. Diğer taraftan ilgili kamu kurumları da göldeki su seviyesinin hızla azaldığı bu günlerde, ortaya çıkan yeni alanların ülke menfaatleri doğrultusunda nasıl kullanılması gerektiğini belirleyebilmek için çeşitli arayışlar içerisine girmiş bulunmaktadır. Oysaki toprak oluşumundaki gelişimler ve değişimler o toprakların üzerinde bulunduğu arazilerin üretkenlik potansiyellerini ve buna bağlı kullanım şekillerini etkilemektedir (Gözükara, 2019). Bu çalışmanın amacı; 1975-2017 yılları arasında, Burdur Gölü'nün alansal değişimi ile bazı iklimsel parametreler arasındaki ilişkiyi değerlendirmek ve karasal ortama çıkan lakustrin materyallerin zamana bağlı konumsal ve alansal dağılımlarını tespit ederek, havzadaki arazi kulanım planlamasına yönelik sayısal veri üretmektir.

\section{Materyal ve Yöntem}

\subsection{Materyal}

Araştırma, Türkiye'nin Göller Bölgesinde yer alan ve Ramsar sözleşmesi kapsamında korunan, Burdur Göl Havza'sının belirli bölümünde yapılmıştır. Çalışma alanı, Isparta ve Burdur il sınırları içerinde $37^{\circ} 32^{\prime}$ $50.65^{\prime \prime}$ ve $29^{\circ} 54^{\prime} 58.51^{\prime \prime} \mathrm{K}$ boylamlar, $37^{\circ} 32^{\prime} 50.65^{\prime \prime}$ ve $30^{\circ} 29^{\prime} 58.39^{\prime \prime}$ D enlemleri ile sinırlı ve $740.22 \mathrm{~km}^{2}$ lik alanı kapsamaktadır (Şekil 1). Çalışma alanı sınırları $10 \mathrm{~m}$ hassasiyete sahip eşyükselti eğrilerinden faydalanılarak yaklaşık $1.000 \mathrm{~m}$ yükseklik ile sınırlandırılmış̧ır (Şekil 1).

Çalışmada, 1975-2017 yıllarına Göl özellikleri ve İklimsel parametreler kullanılmıştır. Buna göre, yıllık ortalama göl seviyesi (m), göl hacmi $\left(\mathrm{hm}^{3}\right)$, yıllık toplam buharlaşma $(\mathrm{mm})$ ve yağış $(\mathrm{mm})$ ile yıllık ortalama sıcaklık $\left({ }^{\circ} \mathrm{C}\right)$ değerleri kullanılmıştır. İklim verileri, Burdur Meteoroloji İstasyonundan, Göl seviyesi ve göl hacmi verileri ise Burdur DSİ 182. Şube Müdürlüğü'nden temin edilmiştir. 

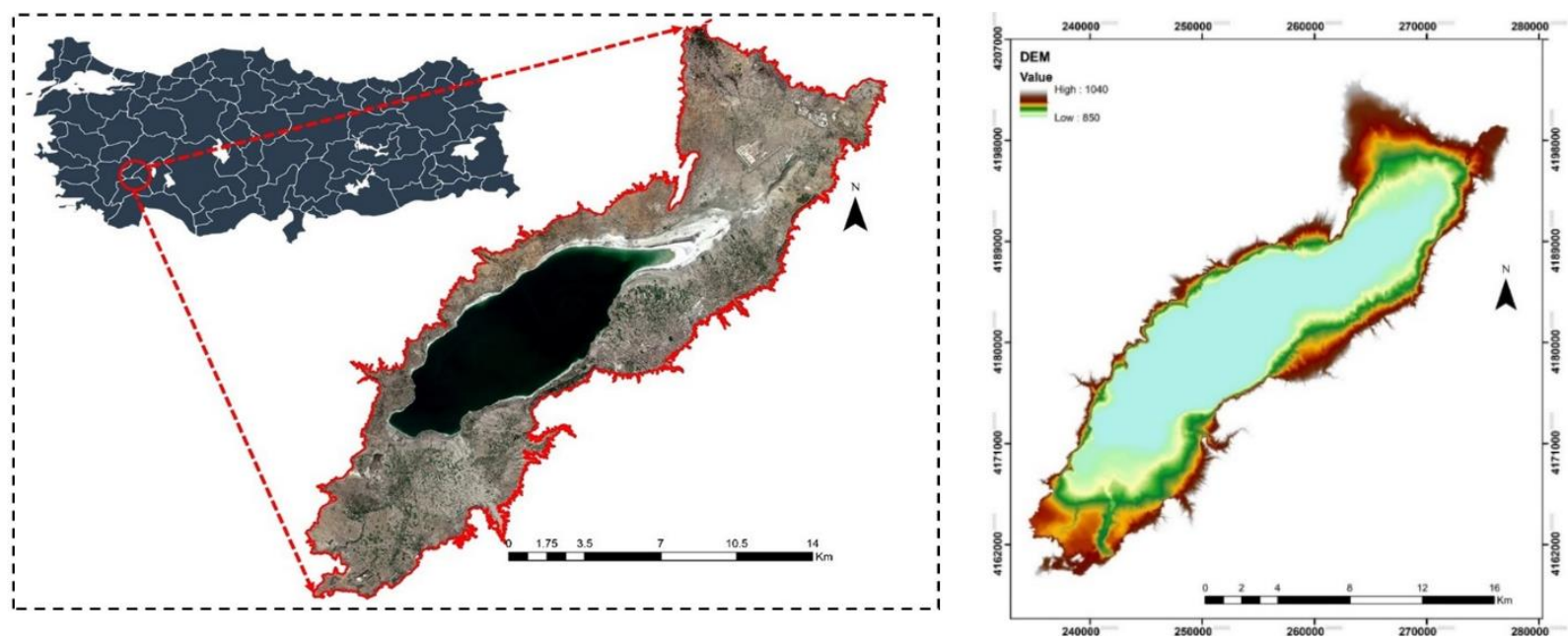

Şekil 1. Çalışma alanı sınırları (a) ve sayısal yükseklik modeli (DEM) (b)

Çalışma alanının güncel iklimsel verilerine göre; serin ve yağış̧ kışlar, sıcak ve az yağışlı-yağışsız yazlar ile Orta Anadolu'nun karasal iklimi ile Akdeniz iklimi arasında değişen bir geçiş iklimi hüküm sürmektedir (Sungur, 1972; Yiğitbaşoğlu ve Uğur, 2010; Atalay, 2012).Uzun yıllık iklimsel verilerinin kullanıldığı Thornthwaite iklim sinıflamasina göre; Burdur İl'i "Yarıkurak-Az Nemli, 2. Derece Mezotermal, Su Fazlası Kışın ve Orta Derecede" olan bir iklim tipine girmektedir (Anonim, 2016).Burdur İli Meteoroloji
İstasyonu tarafindan 1975-2017 yılları arasında kaydedilen iklim verilerine göre; yıllık ortalama sıcaklık $13.34{ }^{\circ} \mathrm{C}$, ortalama toplam yağış $419.01 \mathrm{~mm}$, ortalama toplam yüzey buharlaşması $1202.3 \mathrm{~mm}$ olarak tespit edilmiştir. Çalışma alanının uzun yıllar (19752017) su bilançosu eğrisi, Şekil 2'de verilmiştir. Su bilançosu eğrisinden anlaşılacağı üzere haziran-eylül ayları arasında göreceli olarak yağışın az ve buharlaşmanın fazla olmasından dolayı su açığı tespit edilmiştir (Şekil 2).

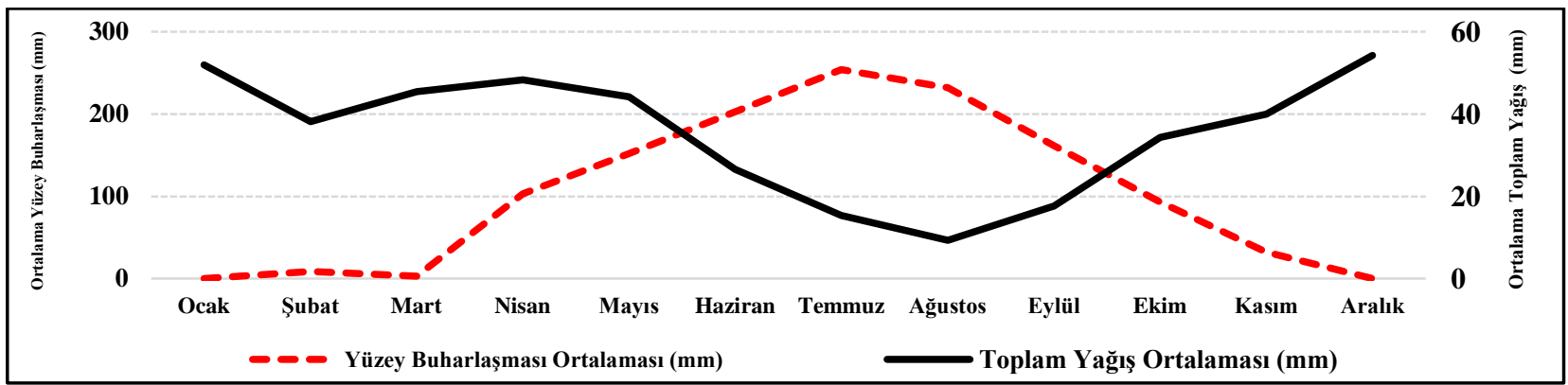

Şekil 2. Burdur iline ait uzun yıllar (1975-2017) su bilançosu diyagramı (Burdur Meteoroloji istasyonundan alınan veriler kullanılarak üretilmiştir)

Burdur Gölü'nün de içinde bulunduğu Burdur Havzas1, tektonik olarak Fethiye-Burdur fay zonundan etkilenmiş tektonik grabendir. Burdur Gölü, FethiyeEğirdir Gölü arasında uzanan Güney Batı Anadolu Fay (GBAF) zonu içerisinde yer alır (Karaman, 1990). Günümüzde tektonik yönden aktif olan Isparta ve Burdur yöresi, eski jeolojik devirlerde de yapısal gerilmelerin etkisi altında kalmış ve değişik tür kıvrıml, kırıklı, bindirmeli ve faylı yapılar kazanmıştır (Erol, 1971; Erol, 1978; Erol, 1979; Erol, 1980; Karaman, 1990; Kış ve ark., 1998). Kuvaterner devrinin Holosen döneminin başlaması ile iklim değişikliği ve havzadaki tektonik hareketlere bağlı çökmeler sonucunda, göl seviyesinde düşüşlerin başladığı belirtilmiștir (Sungur, 1972; Atalay, 1977; Roberts, 2003; Tudryn ve ark., 2013; Atalay, 2017). Araştırma alanı içerisindeki yaygın jeolojik materyaller ise yaşlı alüvyonlar, yeni alüvyonlar ve eski göl tabanlarından ibarettir.

\subsection{Metot}

Sensör özellikleri Çizelge 1'de gösterilen 4 farklı yıl için (1975-1987-2002-2017) temin edilen uydu görüntülerinde ArcGIS 10.2 yazılımı kullanılarak göl sınırları vektör katmanlar olarak sayısallaştırılmış̧ır. $\mathrm{Bu}$ sayede üretilen vektör katmanların alansal büyüklükleri değişimleri CBS ortamında izlenebilmiştir.

Çalışmada kullanılan Landsat ve Sentinel uydu görüntüleri (Şekil 3) United States Geological Survey (USGS) web sitesinden (http://glovis.usgs.gov/) temin edilmiştir. 


\section{Bulgular ve Tartışma}

Büyük su kütleleri, özellikle de karasal ortamlarda yer alan göller; ekolojik, ekonomik ve sosyal anlamda büyük öneme sahip alanlardır. Türkiye'nin
Güneybatısında"Göller Yöresi" olarak bilinen alanda, çok sayıda aktif göl bulunmaktadır. Bu göllerden birisi de Burdur Gölü'dür. Ramsar kriterleri kapsamında, altı metreyi geçmeyen kısımları "sulak alan" olarak tescil edilen bu gölün kimi yerleri, geçmiş jeolojik zaman

Çizelge 1. Çalışmada kullanılan farklı yıllara ait uydu görüntüleri ve özellikleri

\begin{tabular}{ccccc}
\hline Uydu & Sensör & Tarih & $\begin{array}{c}\text { Yersel } \\
\text { Çözünürlük } \\
(\mathrm{m})\end{array}$ & $\begin{array}{c}\text { Radiometrik } \\
\text { Çözünürlük }\end{array}$ \\
\hline Landsat 2 & Multi Spectral Scaner (MSS) & 06.16 .1975 & $60 \mathrm{~m}$ & 6-bit \\
Landsat 5 & Thematic Mapper (TM) & 08.26 .1987 & $30 \mathrm{~m}$ & 8 -bit \\
Landsat 7 & $\begin{array}{c}\text { Enhancement Thematic Mapper } \\
(\text { ETM+) }\end{array}$ & 06.24 .2002 & $15 \mathrm{~m}$ & 8 -bit \\
Sentinel 2 & Multispectral Instrument (MSI) & 07.29 .2017 & $10 \mathrm{~m}$ & 12-bit \\
\hline
\end{tabular}
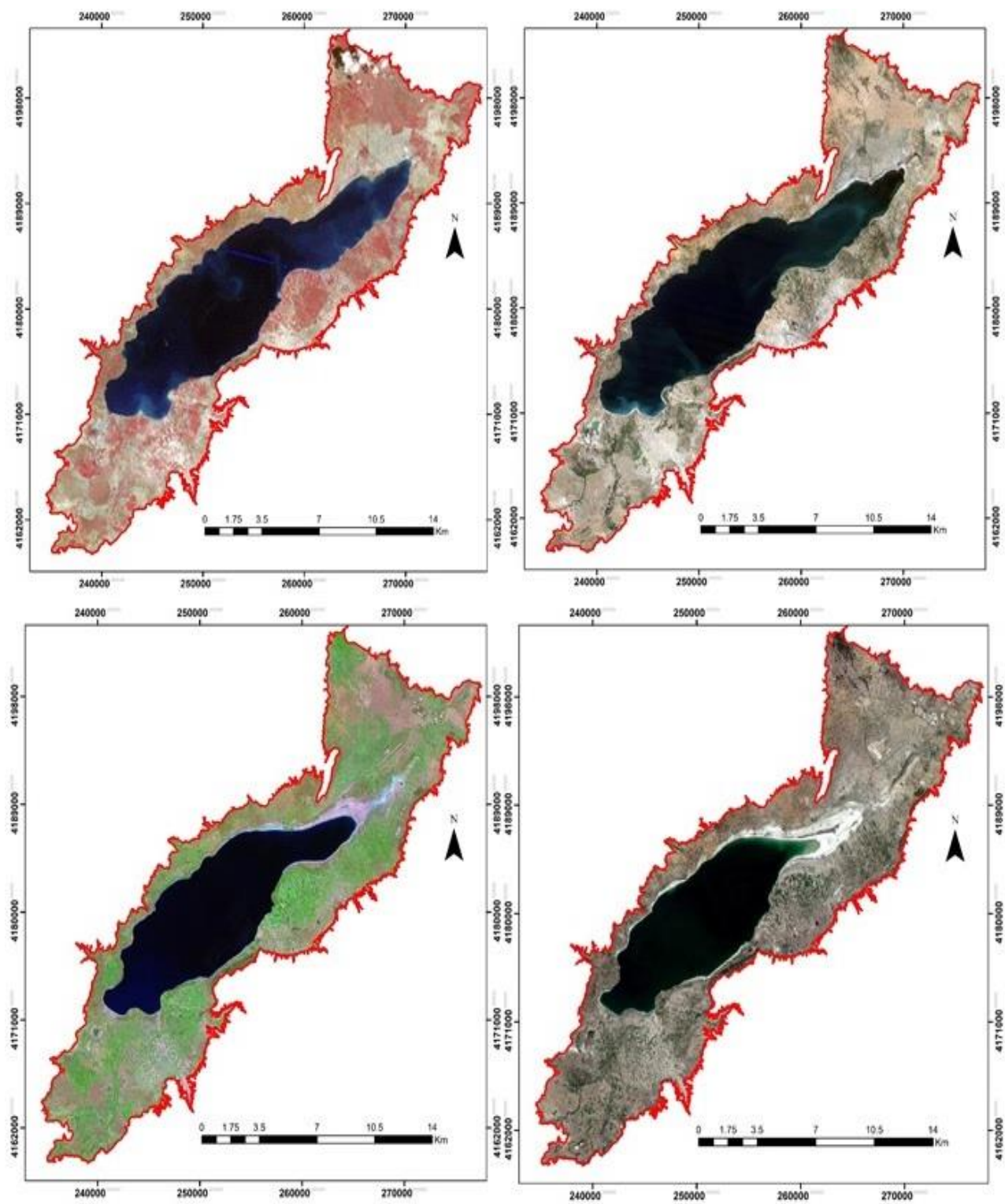

Şekil 3. Çalışma alanının 1975 (a),1987 (b), 2002 (c) ve 2017 (d) yıllarına ait uydu görüntüleri 
süreçlerinde çeşitli kereler ve çeşitli düzeylerde çekilmek suretiyle karasal ortama kavuşmuştur. $\mathrm{Bu}$ gölün havzasında yapılan araştırmalar, son buzul çağının soğuk iklim ve düşük buharlaşma koşullarına bağl1 olarak, gölün su seviyesinin güncel seviyeden yaklaşık $150 \mathrm{~m}$ daha yüksekte olduğuna işaret etmektedir. Holosen döneminin başlaması ile birlikte havzadaki tektonik hareketliliğe bağlı çökmeler sonucunda, topoğrafyaya bağlı gölün dinamik su seviyesinde düşüşlerin başladığ 1 tespit edilmiştir. Burdur Havzası'nın jeomorfolojik gelişiminde ve havzanın günümüzdeki görünümünü almasında Miyosen başlarında Burdur Havzası'nın bulunduğu alanda çökmeler ve kuvaternerde meydana gelen iklim değişimleri önemli rol oynamıştır. (Sungur, 1972; Atalay, 1977; Roberts, 2003; Tudryn ve ark., 2013; Atalay, 2017). Keza bu alanda çalışmalar yapmış olan araştırmacılar, bu gölün su seviyesinde, yakın tarihlerde azalmaların meydana geldiğini ifade etmişlerdir (Girgin ve ark., 2004; Şener ve ark., 2005; Şener ve Morova, 2011; Y1ldırım ve Uysal, 2011; Kahraman, 2013; Keskin ve ark., 2015; Sarp ve Ozcelik, 2017; Gözükara ve ark., 2017; Gözükara ve ark., 2018; Gözükara, 2019). Burdur Gölü'nün özellikle son yıllardaki hızlı seviye kaybı ve nedenleri konusunda maalesef henüz tatmin edici bir çalışma yapılamamıştır. Fakat bazı münferit çalışmalara ve gözlemlere dayanılarak Burdur Gölü'nün su seviyesinin azalmasında; Göl havzasına su taşıyan ana ve yan akarsu kolları üzerine yapılan gölet ve barajlar, iklim değişikliği, tektonik çatlaklar ile suyun ortamdan uzaklaşması, yanlış arazi kullanımı ve tarımsal üretim deseni, tarım ve sanayide kullanılan suya talebin ve tüketimin artması gibi faktörlerin etkili olduğu düşünülmektedir. İklim faktörleri ve diğer faktörlerin etkisi ile Burdur Gölü'nün dinamik su seviyesinde 1975 yılından 2017 yılına kadar 14.36 m'lik bir seviye kaybının olduğu tespit edilmiştir (Şekil 4). Devlet Su İşleri Genel Müdürlüğü (DSI) tarafından kaydedilen verilere göre; Göl seviyesinde meydana gelen bu önemli azalma sonucunda göl hacminde \% 38.34'lük azalmanın meydana gelmiş olduğu tespit edilmiştir (Şekil 4).

Burdur İli Meteoroloji İstasyonu ve Devlet Su İşleri Genel Müdürlüğü (DSİ) tarafindan 1975-2017 yılları arasında kaydedilen iklim verileri ile gölün su seviyesi ve hacim ölçümlerine tanımlayıcı istatistik analizi yapılmışır. Tanımlayıcı istatistik analizlerin sonuçları kapsamında ortalama $(\overline{\mathrm{X}})$, standart hata $\left(S_{\overline{\mathrm{X}}}\right)$, en az ve en fazla ve CV (değişsim katsayısı) değerlerini gösteren tablo Çizelge 2'de gösterilmiştir.

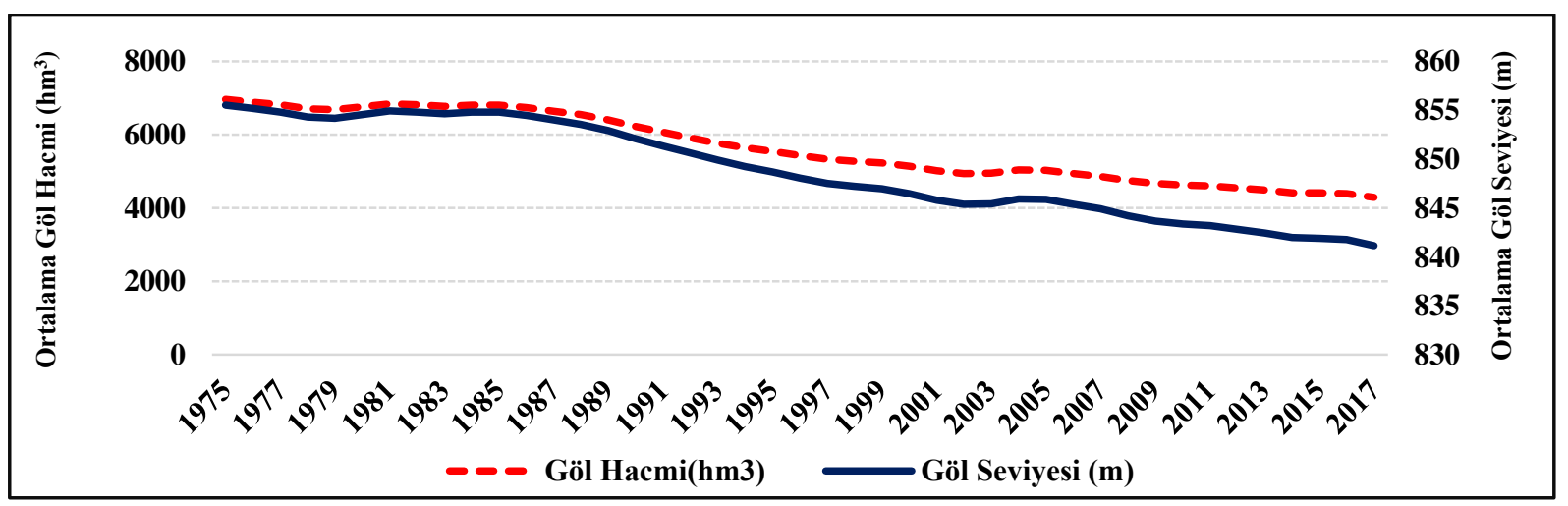

Şekil 4. Burdur Gölü su seviyesi ve hacim değişimleri (DSİ’den alınan veriler kullanılarak üretilmiştir)

Çizelge 2. 1975-2017 yılları arasında yıllık ortalama göl seviyesi, göl hacmi ve iklim parametreleri için tanımlayıcı istatistikler

\begin{tabular}{lcccc}
\hline Parametreler & $\overline{\mathbf{X}} \pm \boldsymbol{S}_{\overline{\mathbf{x}}}$ & En az & En fazla & CV \\
\hline Göl seviyesi (m) & $848.85 \pm 0.74$ & 841.15 & 855.51 & 0.57 \\
Göl hacmi $\left(\mathrm{hm}^{3}\right)$ & $5642 \pm 141$ & 4292.50 & 6961.28 & 16.36 \\
Buharlaşma $(\mathrm{mm})$ & $99.86 \pm 1.72$ & 846.30 & 1552.80 & 11.26 \\
Yağış $(\mathrm{mm})$ & $419.0 \pm 12.9$ & 276.40 & 594.2 & 20.23 \\
Sicaklık $\left({ }^{\circ} \mathrm{C}\right)$ & $13.34 \pm 0.113$ & 11.67 & 15.37 & 5.58 \\
\hline
\end{tabular}



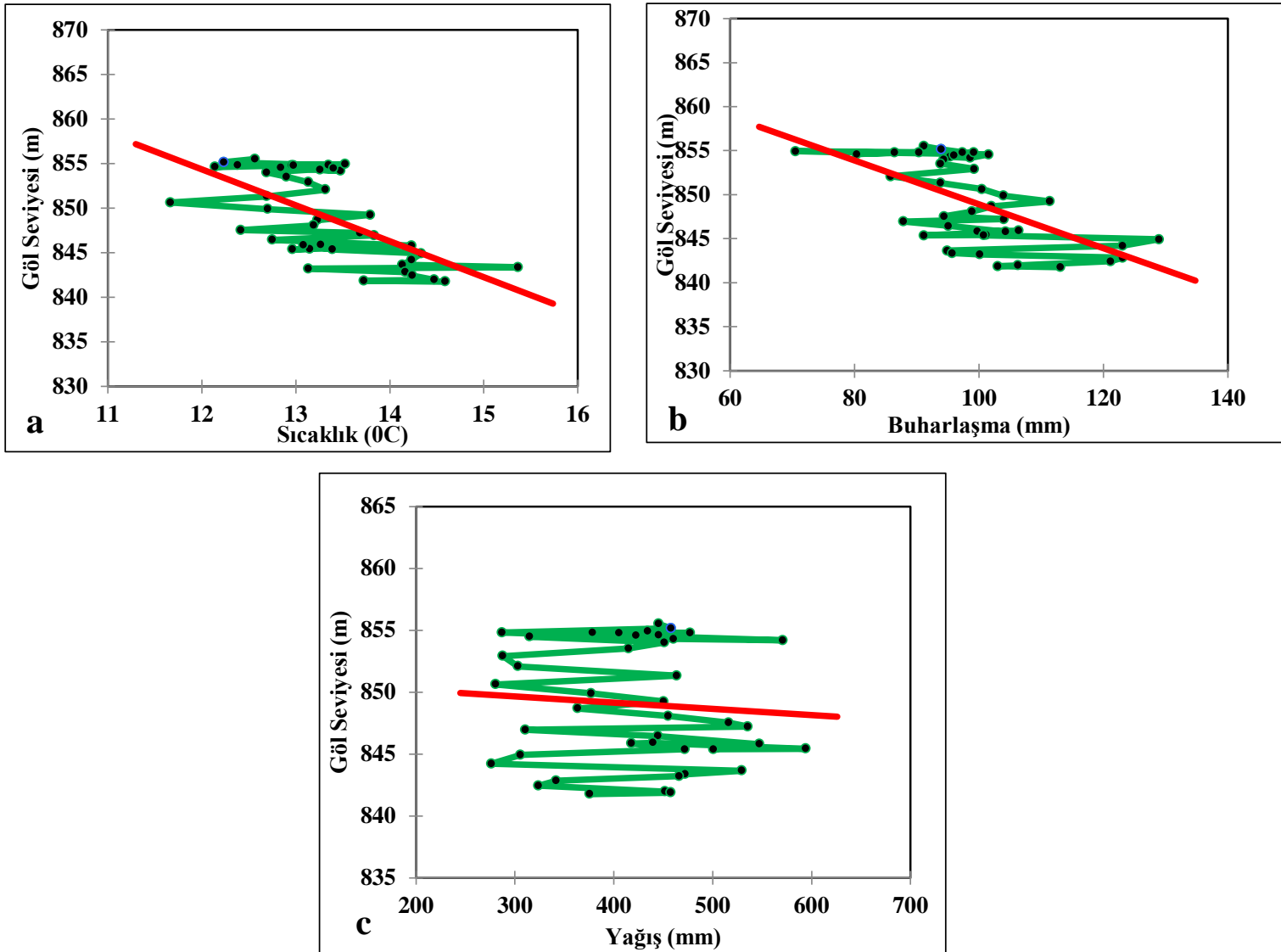

Şekil 5. 1975-2017 yılları arasındaki ortalama sıcaklık, toplam ortalama buharlaşma ve ortalama yağış verilerinin dağılımları

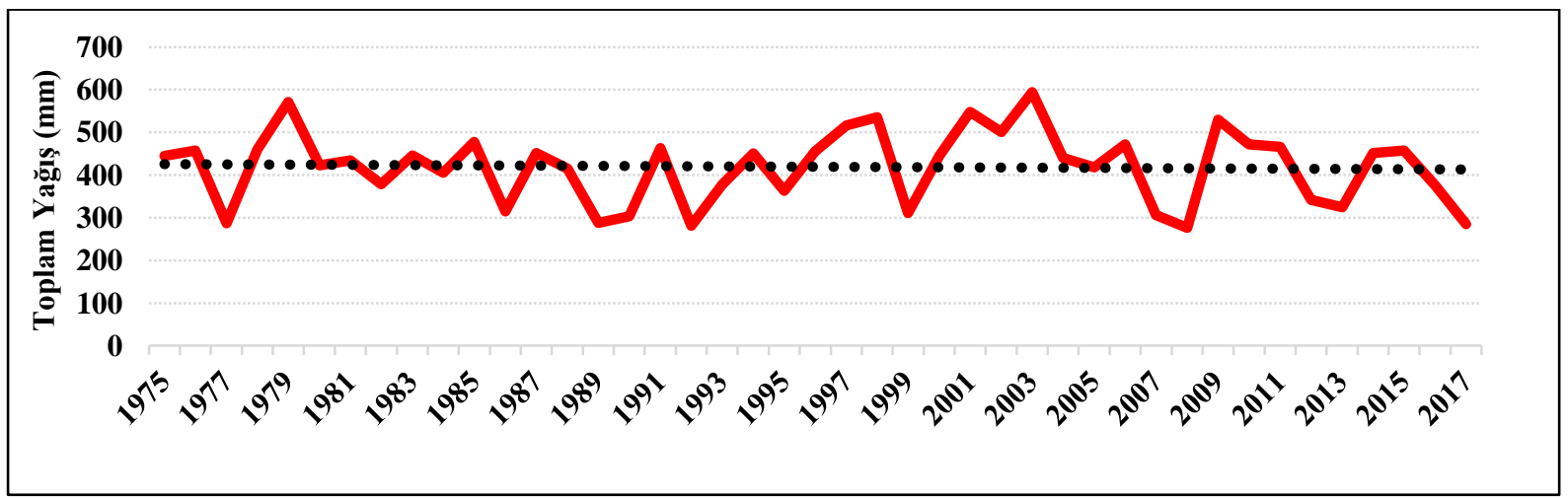

Şekil 6. Çalışma alanının 1975-2017 yılları arasındaki yağış ve buharlaşma verileri (Burdur Meteoroloji istasyonundan alınan veriler kullanılarak üretilmiştir)

Göl özellikleri ve İklimsel parametrelerin araştırma yılları arasında Çizelge 2'deki CV değerleri Şekil 5'te ortalama sicaklık, toplam ortalama buharlaşma ve ortalama toplam yağış verilerinin dağılımları incelendiğinde; en az değişim katsayısının $(\mathrm{CV}=0.57)$ göl seviyesinde, en fazla değişim katsayısının ( $\mathrm{CV}=$ 20.23) yağışta meydana geldiği tespit edilmiştir (Çizelge 2). Yağıştaki bu büyük değişimi değerlendiren Burdur Meteoroloji İstasyonu, 1970-1977 yılları arasını kurak dönem, 1977-1985 yılları arasını yağışlı dönem,
1985-1995 yılları arasını kurak dönem, 1995-2006 yılları arasını yağışlı dönem, 2006-2008 yılları arasını kurak dönem, 2008-2011 ise devamlı artan eğilimli yağışılı dönem olarak belirlemiştir (Anonim, 2014).

İklimsel parametrelerin 1975-2017 yılları arasındaki değerleri incelendiğinde; çeşitli düzeylerde salınımlar olmakla birlikte, yağış değerlerinde çok küçük oranda azalış olduğu (Şekil 6), buna karşılık sıcaklık ve buharlaşma değerlerinde ise 2017 yılına doğru artış olduğu tespit edilmiştir (Şekil 7 ve Şekil 8). 


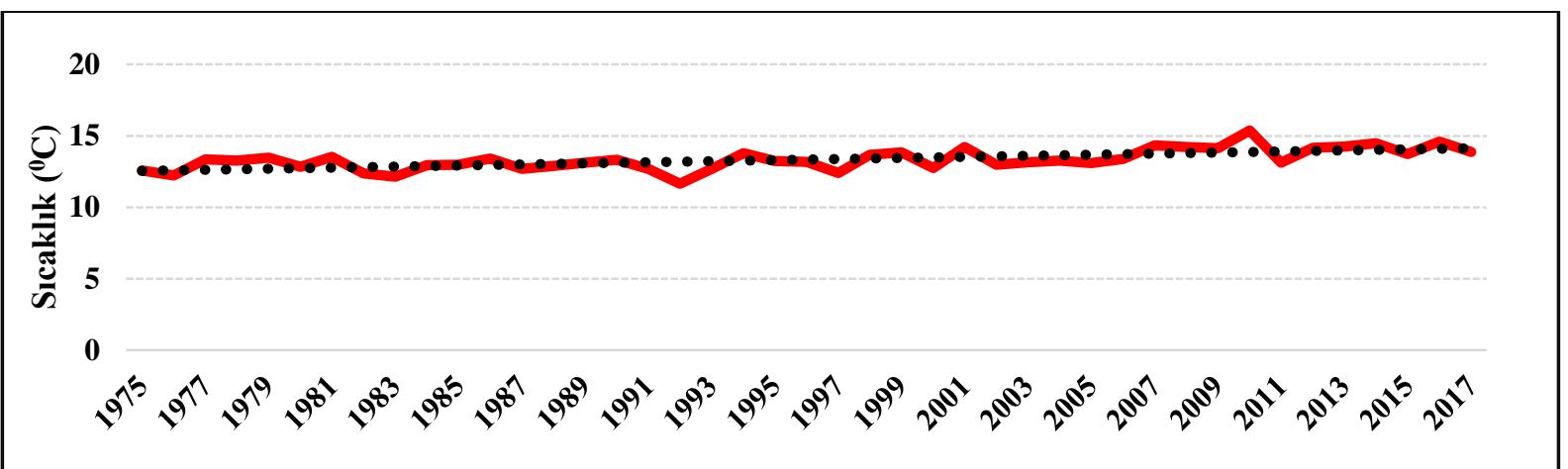

Şekil 7. Çalışma alanının 1975-2017 yılları arasındaki sıcaklık verileri ve eğilim çizgisi (Burdur Meteoroloji istasyonundan alınan veriler kullanılarak üretilmiştir)

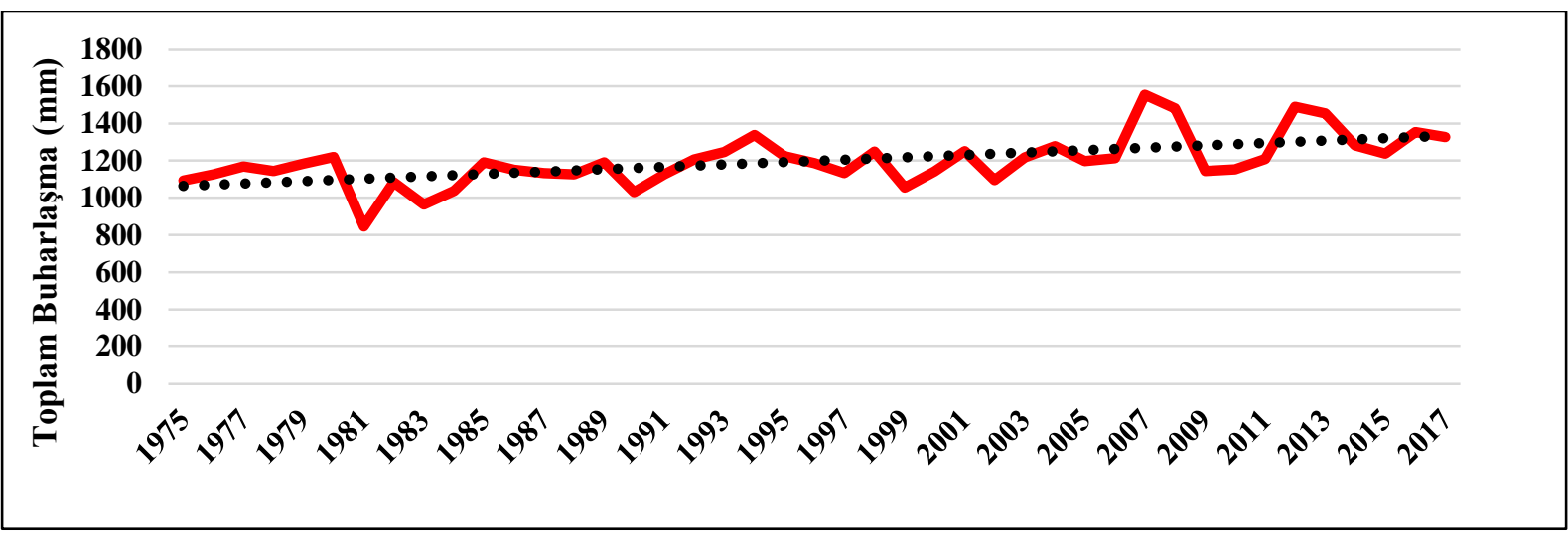

Şekil 8. Çalışma alanının 1975-2017 yılları arasındaki toplam buharlaşma verileri ve eğilim çizgisi (Burdur Meteoroloji istasyonundan alınan veriler kullanılarak üretilmiştir)

Etkili olduğu düşünülen bu faktörlerden iklim değişikliğinin göl seviyesindeki düşüşler ile ilgisini açılayan korelasyon analiz sonuçları Çizelge 3'te gösterilmiştir. Göl seviyesindeki azalış ile en güçlü negatif korelasyonun (ilişkinin) sırasıyla; sıcaklık ($0.637 * *)$ ve buharlaşma $(-0.603 * *)$ arasında olduğu tespit edilmiştir (Çizelge 3).

1990’lı yılların başından itibaren yağışlar artış göstermesine rağmen, göl seviyesinde azalma düzenli bir şekilde devam etmiştir. Özellikle, 1987-2002 yılları arasında şiddetli su kayıpları tespit edilmiştir. Burdur'da 2003 yılında son 56 yılın en yüksek yağģs seviyesinin $(594.2 \mathrm{~mm})$ görülmesi, göl seviyesindeki düşüşü geçici olarak durdursa da, su seviyesindeki alçalma devam etmiştir. Şener ve ark. (2005) göl suyu seviyesindeki alçalmayı, 1985-1995 yılları arasındaki kurak döneme, sonraki yıllardaki alçalmanın büyük bir kısmını ise Burdur Gölü'nü besleyen ana ve yan akarsu kolları üzerinde yapımı tamamlanan barajlar ve göletler ile ilgili olduğunu ifade etmişlerdir.

Çizelge 3. Göl seviyesi ile iklim parametreleri arasındaki korelasyon

\begin{tabular}{lccccc}
\hline Parametreleri & GS $(\mathrm{m})$ & $\mathrm{GH}\left(\mathrm{hm}^{3}\right)$ & $\mathrm{B}(\mathrm{mm})$ & $\mathrm{Y}(\mathrm{mm})$ & $\mathrm{S}\left({ }^{\circ} \mathrm{C}\right)$ \\
\hline Göl Seviyesi (m) & 1 & $\mathbf{0 . 9 9 8 * *}^{* *}$ & $\mathbf{- 0 . 6 0 3 * *}$ & -0.021 & $\mathbf{- 0 . 6 3 7 ^ { * * }}$ \\
\hline Göl Hacmi $\left(\mathrm{hm}^{3}\right)$ & 1 & $-0.601^{* *}$ & -0.029 & $-0.622^{* *}$ \\
\hline Buharlaşma (mm) & & 1 & -0.268 & $0.499^{* *}$ \\
\hline Yağı̧̧ $(\mathrm{mm})$ & & & 1 & -0.056 \\
\hline Sıcaklık $\left({ }^{\circ} \mathrm{C}\right)$ & & & & 1
\end{tabular}

GS (Göl seviyesi), GH (Göl hacmi), B (Buharlaşma), Y (Yă̆lş), S (Sıcaklık) ve NM (Nispi Nem)

** $1 \%$ Seviyesinde önemli 

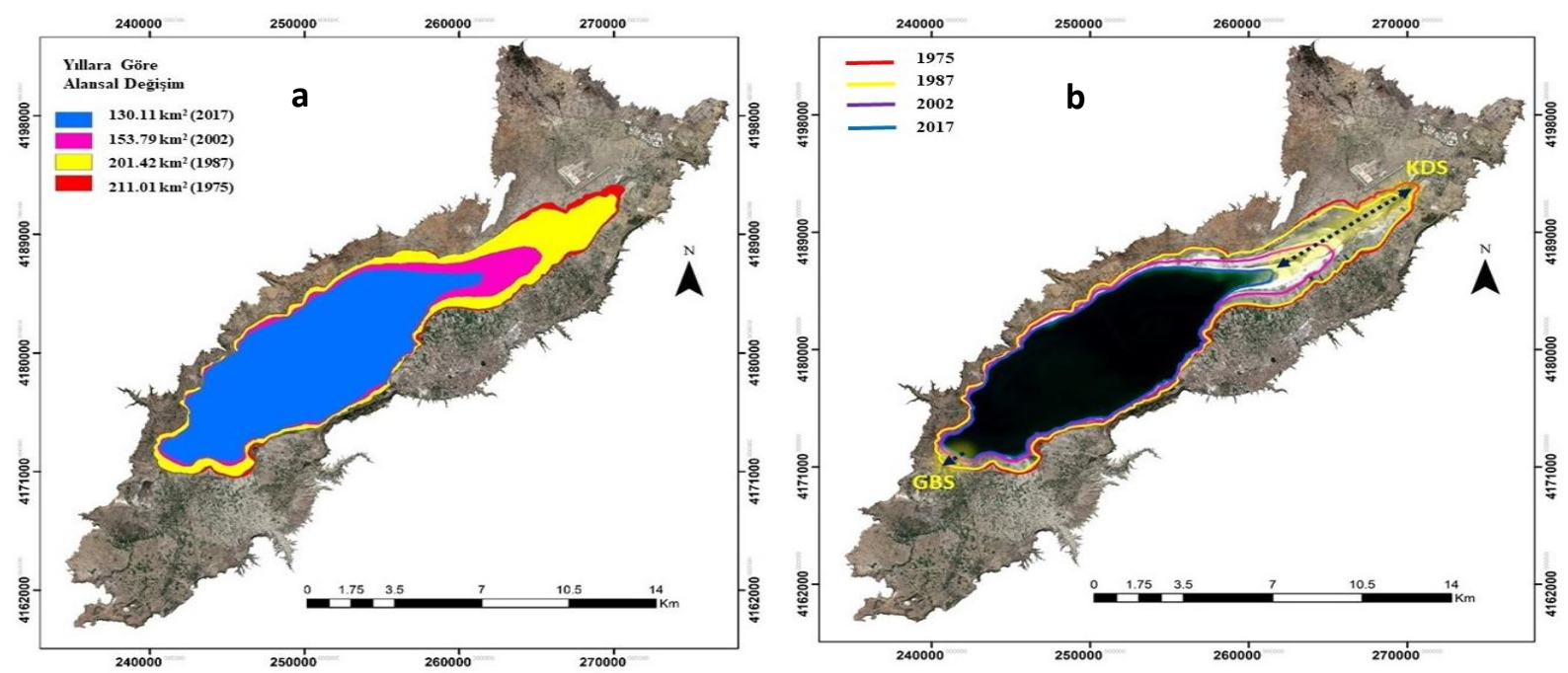

Şekil 9. Burdur Gölü’nün 1975, 1987, 2002 ve 2017 yıllarındaki değişimi (a) ve ortaya çıkan lakustrin ana materyalin KDS ve GBS'e göre alansal dağılımı (b)

Göl seviyesindeki 1975-2017 yılları arasındaki 42 y1llık süreçte meydana gelen azalma, 4 farklı zamana ait uydu verisi üzerinde yürütülen sayısal analizler ile tespit edilmiş ve bu azalmanın ortaya çıkarmış olduğu lakustrin materyallerin (yeni arazi parçalarının) zamansal ve mekansal dağılımları Şekil 9a-b'de gösterilmiştir.

$\mathrm{Bu}$ analizlerin sonucuna göre; 1975-1987 yılları arasında göreceli olarak daha düşük olan göl kurumasının 1987-2002 yılları arasında en yüksek düzeye ulaştığı ve 2002-2017 yılları arasında da bir önceki döneme yakın, ciddi bir kuruma yaşadığı tespit edilmiştir. Şekil 9a ve Şekil 9b birlikte incelendiğinde; 1975-2017 yılları arasındaki göl çekilmeleri neticesinde ortaya çıkmış olan karasal materyallerin gölün güneybatı taraflarına kıyasla, kuzeydoğu taraflarında daha geniş alanlar kapladığı görülmektedir. Keza 2017 yılındaki göl kıyı çizgisi ile 1975 yılına ait uydu görüntüsü üzerindeki eski göl kıyı çizgisi esas alındığında; iki kıyı çizgisi arasındaki mesafenin gölün güneybatı tarafında $1.19 \mathrm{~km}$, gölün kuzeydoğu tarafında ise $11.34 \mathrm{~km}$ olduğu tespit edilmiştir. Söz konusu bu mesafelere ilişkin kot yüksekliklerinin de dikkate alındığı bir hesaplama yapıldığında; gölün güneybatı kısmındaki kuruyan (karasal ortama çıkmış olan) alanın ortalama eğiminin \% 1.16, buna karşıllık kuzeydoğu tarafta karasal ortama çıkmış olan arazilerin ortalama eğiminin ise \% 0.12 olduğu anlaşılmaktadır. $\mathrm{Bu} \mathrm{da;}$ Burdur Gölü'nün geçmişten günümüze kadar güneybatı taraflarının daha derin ve şelf eğimlerinin daha fazla, buna karşılık kuzeydoğu taraflarının ise daha sı ğ ve şelf eğimlerinin daha sı̆̆ olduğunu göstermektedir. Buraya kadar yapılmış olan söz konusu bu analizlerin ve tespitlerin en önemli sonucu ise; Burdur gölünü besleyen ve aynı zamanda göl tabanına materyal taşıyıp biriktiren en önemli akarsu kaynaklarının bu havzanın kuzeydoğu taraflarında yoğunlaşmış olduğudur. $\mathrm{Bu}$ durum dikkate alınması gereken son derece önemli bir bulgudur.

\section{Sonuç}

Yapılan araştırma ve değerlendirmeler sonucunda, Burdur Gölü'nün dinamik su seviyesinde 1975 yılından 2017 yılına kadar 14.36 m'lik bir seviye kaybı ve göl hacminde de \% 38.34'lük bir azalmanın yaşandığı tespit edilmiştir. Burdur Gölü'nün 1975 yılında kapladığı alan $211.01 \mathrm{~km}^{2}$ iken 2017 yılında kapladığ 1 alan ise 130.11 $\mathrm{km}^{2}$ ye kadar gerilemiştir. Bu tespit sonucunda 1975 yılından 2017 yılına kadar Burdur Gölü'nün alansal olarak -\% 38.34 küçüldüğü ve ortaya $80.90 \mathrm{~km}^{2}$ güncel lakustrin materyalin çıktığı tespit edilmiştir. 2017 yılına ait uydu görüntüsündeki göl kıyı çizgisi ile 1975 yılına ait uydu görüntüsündeki göl kıyı çizgisi karşılaştırıldığında, iki kıyı çizgisi arasındaki mesafenin gölün güney batı tarafinda $1.19 \mathrm{~km}$, gölün kuzey doğu tarafinda ise $11.34 \mathrm{~km}$ olduğu bulunmuştur. Söz konusu bu mesafelere ilişkin kot yüksekliklerinin dikkate alınarak yapılan hesaplamalarında ise gölün güneybatı kısmındaki kuruyan (karasal ortama çıkmış olan) alanın ortalama eğimin \% 1.16 buna karşıllık kuzeydoğu tarafta karasal ortama çıkmış olan arazilerin ortalama eğiminin ise \% 0.12 olduğu anlaşılmaktadır. Bu azalmanın ortaya çıkarmış olduğu lakustrin materyallerin gölün güneybatı taraflarına kıyasla kuzeydoğu taraflarında daha geniş alanlar kapladığı görülmektedir. Burdur Gölü’nün su seviyesinin azalması ile iklimsel parametreler arasındaki ilişkiler incelendiğinde; göl seviyesindeki azalma ile sicaklık ve toplam buharlaşma arasında yüksek korelasyon tespit edilirken, toplam yağı̧̧ ile arasında herhangi bir korelasyon tespit edilememiştir. Araştırma yılları içinde 1975 yılından 2017 yılına kadar ortalama 
yillık sicaklı $\left({ }^{0} \mathrm{C}\right)$ ve toplam buharlaşma $(\mathrm{mm})$ miktarları, belirli oranda artış eğiliminde iken toplam yağış (mm) miktarı kısmi de olsa azalma eğilimde olduğu bulunmuştur. Burdur Gölü'nün kurumasinda etkili olduğu düşünülen iklim faktörlerine, müdahale edilerek göl havzasının su bilançosu üzerindeki baskısının azaltılması mümkün görünmemektedir. $\mathrm{Bu}$ sebeple Burdur Göl Havza'sında, gölün kuruması üzerinde baskısı olan ve insan eliyle müdahale edilerek düzeltilmesi mümkün olan,hatalı arazi kullanımı ve hatalı tarımsal üretim deseni üzerinde gerekli düzenlemelerin acilen yapılması gerekmektedir.Bu gereklilikten hareketle,araştırmamız vb çalışmaların temel olarak ele alındığı, özellikle Burdur Göl Havza'sında zamana ve mekana bağl1,toprak oluşum ve gelişim düzeylerinin tespit edilerek arazi kullanım planlaması ile birlikte, sulu tarıma uygunluk sınıflamalarının,tarımsal kullanımlara uygunluk derecelerinin ve tarımsal üretim modellerinin belirlenmesi gerekmektedir. Böylelikle yöredeki yeraltı ve yerüstü su kaynaklarının rasyonel yönetimine katkı sağlanabilecektir. Aynı zamanda ülkemizin en önemli sulak alanlarından birisi olan ve özellikle son yıllarda hızla kuruyan Burdur Gölü'nün devamlılığının sağlanmasında,önemli bir adım atılacaktır. Nihayetinde yakın geçmişte su altından, karasal ortama geçen lakustrin ana materyallerin sınırlarının ve özelliklerinin belirlenmesi son derece önemlidir. Çünkü bu alanların bir kısmı tarımsal üretime uygun, bir kısmı ise sahip oldukları sınırlayıcı özellikleri nedeniyle kesinlikle uygun değildir. Genellikle tarımsal üretim amacı için talep edilen ve yerel yönetimler üzerinde ciddi bask1 oluşturan bu alanların, yetenekleri doğrultusunda kullanılması gerekmektedir. Yapılacak iyi bir arazi kullanım planlaması ve yasal düzenlemeler ile alan kullanım talepleri üzerinde baskılar azalacak, alan amacı doğrultusunda kullanılacak böylelikle ekosistem üzerinde olumlu dengeler ve gelişmeler sağlanacaktır. İyi yönde değişen ve gelişen çevresel koşullarla, yöre insanının doğayı ve doğal kaynakları daha efektif kullanması sağlanacak, sonuç olarak toplumsal değişim ivme kazanacaktır.

\section{Teşekkür}

$\mathrm{Bu}$ çalışma, FBA-2017-2800 numaralı Araştırma Projesinin bir bölümüdür. Katkılarından dolayı Akdeniz Üniversitesi Bilimsel Araştırma Projeleri Yönetim Birimine teşekkür ederiz.

\section{Kaynaklar}

Akar, İ., Maktav D., Günal, N., 2012. Determination of changes in lake surface using different digital image processing techniques. Journal of Aeronautics and Space Technologies 5 (4): 35-51.

Altunbaş, S., M. Sarı., 2010. Türkiye ölçeğinde sulak alan yönetim planlarının durumu; Eğirdir Gölü yönetim planı örneği. I. Ulusal Toprak ve $\mathrm{Su}$ Kaynakları Kongresi, Eskişehir, s: 34.
Altunbaş, S., Sarı, M., 2011. Kurutulan kestel gölünden kazanılan toprakların bazı özellikleri ile üretim potansiyelleri arasındaki ilişkiler. Akdeniz Üniversitesi. Ziraat Fakültesi Dergisi, 24 (1):61-65.

Anonim, 2013. Burdur gölü sulak alan alt havzası biyolojik çeşitlilik araştırması. T.C. Orman ve Su İşleri Bakanlığı, Doğa Koruma ve Milli Parklar Genel Müdürlüğü Yayınları. Atalay, İ. 1977. Burdur Havzası ve çevresinin jeomorfolojik gelişimi (Geomorphological evaluation of the Burdur Basin and its surroundings. Jeomorfoloji Dergisi, 6: 93110.

Atalay, İ., 2012. Uygulamalı Klimatoloji. Meta Basım, İzmir.

Atalay, İ., 2017. Türkiye Jeomorfolojisi. Meta Basım, İzmir.

Ataol, M., 2010. Burdur Gölü'nde seviye değişimleri. Coğrafi Bilimler Dergisi, 8 (1): 77-92.

Bahadır, M., 2013. Determination of Spatial Changes of Akşehir Lake with Remote Perception Techniques. Marmara Coğrafya Dergisi. 28: 246-275.

Baktır, İ., Sarı, M., 2002. Lake Avlan and its influences on ecological balance and socio-economic status of Elmalı County, EPMR-2002, Int. Conference, Nicosia-Northern Cyprus. Session 11: Economic impact of environmental changes, p: 193.

Bassi, N., Dinesh Kumar, M., Sharma, A., ParthaSaradhi, P., 2014. Status of wetlands in India: a review of extent, ecosystem benefits, threats and management strategies. Journal of Hydrology 2: 119.

Brinson, M.M., Malvarez, A., 2002 Temperate freshwater wetlands: types, status and threats. Environmental Conservation 29 (02):115-133.

Çatal A., Dengiz, O., 2015. Akşehir Gölü’nün Akşehir Çölü'ne dönüşü süreci ve etki eden faktörleri. Toprak Su Dergisi. 4 (1): 18-26.

Celebi, M., 2016. Ecological Importance of wetlands and samples in Konya Closed Basin. International Journal of Scientific Research in Science \& Technology 2 (3): 323-333.

Cui, B.S., He, Q., Gu, B.H., Bai, J.H., Liu, X.H., 2016. China's coastal wetlands: understanding environmental changes and human impacts for management and conservation. Wetlands 36:1-9.

Erol, O., 1971. Konya, Tuz Gölü, Burdur Havza'larındaki pluvial göllerin çekilme safhalarının jeomorfolojik delilleri. Coğrafya Araştırmaları Dergisi, 3-4: 13-52.

Erol, O., 1978. The Quaternary history of the Lake Basins of Central and Southern Anatolia. In: Brice, W.C. (Ed.), The environmental history of the Near and Middle East since the last ice age. Academic Press, London, pp. 111-139.

Erol, O., 1979. Dördüncü çağ (kuvaterner) jeoloji ve jeomorfolojisinin ana çizgileri. Ankara Üniversitesi Dil ve Tarih-Coğrafya Fakültesi Yayımlari No:289, Ankara. 
Erol, O., 1980. Anadolu'da Kuaterner pluvial interpluvial koşullar ve özellikle İç Anadolu'da son buzul çağından bugüne kadar olan çevresel değişimler. Coğrafya Araştırmaları Dergisi, 9: 5-16.

Fickas, K.C., Kohen, W.B., Yang, Z., 2016. Landsatbased monitoring of annual wetland change in the Willamette Valley of Oregon, USA from 1972 to 2012. Wetlands Ecology and Management 24:7392.

Girgin, S., Kazanc1, N., Dügel, M., 2004. On the limnology of deep and saline lake Burdur in Turkey. Acta Hydrochim. Hydrobiol, 32 (3): 189-200.

Gözükara, G., Altunbaş, S., 2016. Lakustrin materyal üzerinde gelişen toprak özellikleri. 3. Ulusal Tarım Kongresi, Afyon. 05 - 08 Ekim. s.81.

Gözükara, G., Altunbaş, S., Sarı, M., 2017. Determination of land change near the burdur lake by using remote sensing and geographic information systems. 5th International Participation Soil and Water Resources Congress, Kirklareli. S.24.

Gözükara, G., Altunbaş, S., Sarı, M., 2018. Evaluation of the effect of some climatic parameters on timedependent spatial variation of lake burdur; 19752017. 2017. International Ecology 2018 Symposium. Kastamonu. S.68.

Gözükara, G., 2019. Eski göl tabanlarındaki zamansal ve mekansal değişimlerin toprak oluşumuna etkileri. Akdeniz Üniversitesi, Fen Bilimleri Enstitüsü, Toprak Bilimi ve Bitki Besleme Anabilim Dall, Doktora Tezi.

Günal, N., Özdemir, Y., 2010 Determination of surface change of Neyriz Lake (Iran) by using multitemporal satellite imagery. III. Uzaktan Algilama ve Coğrafi Bilgi Sistemleri Sempozyumu, 11 - 13 Ekim 2010, Gebze - Kocaeli.

Hartig, E.K., Grozev, O., Rosenzweig, C., 1997. Climate change, agriculture and wetlands in Eastern Europe: vulnerability, adaptation and policy. Climatic Change 46: 101-121.

Hui, F., Xu, B., Huang, H., Yu, Q., Gong, P., 2008 Modelling spatial-temporal change of Poyang Lake using multitemporal Landsat imagery. International Journal of Remote Sensing 29 (20): 5767-5784.

Kahraman, N., 2013. Water receding in Burdur Lake and solution proposals. 3rd International Geography Symposium - GEOMED. 111-123.

Karaman, M. E., 1990. Isparta güneyinin temel jeolojik özellikleri. Türkiye Jeoloji Bülteni, 33, 57 - 67.

Keskin, M.E., Taylan E.D., Aslanbaş, T., 2015. Eğirdir ve Burdur Gölleri su seviyelerinde olası azalma eğilimleri. 4.Su Yapıları Sempozyumu. Antalya.

Kent, J.B., Mast, N., 2005 Wetland change analysis of san dieguito lagoon, California, USA: 1928-1994. Wetlands 25 (3):780-787.

Kış, M., Erol, O., Şenel, S., Ergin, M., 1998. Prelimnary results of radiocarbon dating of coastal deposits of the pluvial lake of Burdur, Turkey. Journal of Islamic Academy of Sciences, 2:37-40.
Liu, Y., Yue, H., 2017. Estimating the fluctuation of Lake Hulun, China, during 1975-2015 from satellite altimetry data. Environmrntal Monitoring Assessment 189:630.

Merkt, J., Luttig, G., Schneekloth, H., 1971. Vorschlag zur Troels-Smith J. 1955. Karakterisering af løse jordarter Danmarks Gliederung and Definition der Limnischen Ledimente. Geologis- Geologiske Undersøgelse Series IV. 3(10), 73 pp. chishes Jahrbuch 89: 607-623.

Roberts, N., Karabıyıklığllu, M., Jones, M., Mather, A., Jones, G., Rodenberg, I., Eastwood, W.J., KapanYeşilyurt, S., Yiğitbaşıŏglu, H., Watkinson, M., 2003. Climatic and tectonic controls over late quaternary sedimantation in the Burdur Lake Basin, Southwest Turkey, 3rd International Limnogeology Congress, USA.

Sarı, M., Altunbaş, S., Sönmez, N.K., Emrahoğlu, E.I., 2003. Farklı fizyografik üniteler üzerinde yer alan eski Manay göl alanı topraklarının özellikleri ve potansiyel üretkenlikleri. Akdeniz Üniversitesi Ziraat Fakültesi Dergisi, 16 (1), 7-17.

Sarı, M., 2015. Taşınmış anamateryal ile yer şekilleri arasındaki ilişkiler. (Ed. Şenol S., Küsek G., Sarı M., Kurucu Y.) Toprak Etüd Haritalama El Kitabı. Ankara. S.52-109.

Sarp, G., Ozcelik, M., 2017. Water body extraction and change detection using time series: A case study of Lake Burdur, Turkey. Journal of Taibah University for Science, 11: 381-391.

Schnurrenberger, D., Russell, J., Kelts, K., 2003. Classification of lacustrine sediments based on sedimentary components. Journal of Paleolimnology, 29: 141-154.

Sungur, K., 1972. Burdur Acıgöl depresyonları ve Tefenni Ovası'nın Fiziki Coğrafyası. İstanbul Üniv. Coğrafya Enst. Yay. Nu. 95, İstanbul.

Soil Survey Manuel., 2017. United States department of agriculture. Agriculture Handbook. No:18.

Song, H., Liu, X., 2016. Anthropogenic effects on fluxes of ecosystem respiration and methane in the yellow river estuary, China. Wetlands 36 (1):113123.

Stephanie, A.I., Robert, J.N., Scott, R.E., 2000. Indicators and assessment methods for measuring the ecological integrity of semiaquatic terrestrial environments. Hydrobiologia 422 (2):111-131.

Şener, E., Davraz, A., Ismailov, T., 2005. Burdur Gölü seviye değişimlerinin çok zamanlı uydu görüntüleri ile izlenmesi. Türkiye Kuvaterner Sempozyumu Turqua-V, İTÜ Avrasya Yer Bilimleri Enstitüsü, 2-5 Haziran 2005. İstanbul, 148.

Şener, E., Morova, N., 2011. Modeling of water level changing of burdur lake with fuzzy logic and linear regression analysis. Süleyman Demirel Üniversitesi, Fen Bilimleri Enstitüsü Dergisi, 15 (1): 60-66.

Tudryn, A., Tucholka P., Özgür N., Gibert E., Elitok O., Kamaci Z., Massault M., Poisson A., Platevoet B., 2013. A 2300-year record of environmental change 
from SW Anatolia, Lake Burdur, Turkey. Journal of Paleolimnol, 49: 647-662.

Troels-Smith, J., 1955. Karakterisering af løse jordarter Danmarks Geologiske Undersøgelse Series IV. 3 (10), 73 pp.

Yıldırım, Ü., Uysal, M., 2011. Changes in the coastline of the burdur lake Between 1975 and 2010. International symposium on environmental protection and planning: Geographic Information Systems (GIS) and Remote Sensing (RS) Applications (ISEPP) 28-29 June 2011, IzmirTurkey.
Yan, X., Hu, Y., Chang, Y., Zhang, D., Liu, M., Guo, J., Ren, B., 2017. Monitoring wetland changes both outside and inside reclamation areas for coastal management of the Northern Liaodong Bay, China. Wetlands 37:885-897.

Yiğitbaşoğlu, H., Uğur, A., 2010. Burdur Gölü havzasında arazi kullanım özelliklerinden kaynaklanan çevre sorunları. Ankara Üniversitesi Çevre Bilimleri Dergisi, 2-2, 129-143.

Zedler, J.B., (2003) Wetlands at your service: reducing impacts of agriculture at the watershed scale. Frontiers in Ecology and the Environment 1:65-72. 